\title{
Protein quality of pigeonpea (Cajanus cajan (L.) Millsp.) as influenced by seed polyphenols and cooking process
}

\author{
U. SINGH \\ International Crops Research Institute for the Semi-Arid Tropics (ICRISAT), Patancheru, \\ Andhra Pradesh 502 324, India
}

Received 20 July 1991; accepted 28 October 1991

Key words: Pigeonpea, biological evaluation, polyphenols, fibers, cooking process

\begin{abstract}
True protein digestibility (TD), biological value (BV), and net protein utilization (NPU) of low-polyphenol pigeonpea cultivars (Nylon, BDN 2, and ICPL 87067) were significantly higher than those of the high polyphenol cultivars (C 11, ICPL 87, and ICPL 151) when whole-seed samples were compared. Most of the polyphenols $(80-90 \%)$ were concentrated in the seed-coat. Dhal (decorticated split cotyledons) samples of low (Nylon) and high (C 11) polyphenol cultivars revealed no large differences in TD, BV, and NPU values of these cultivars. This indicated an adverse affect of seed-coat polyphenols on protein quality of pigeonpea whole-seed. The cooking process significantly increased TD in both whole seed and dhal samples. BV of both whole-seed and dhal samples was reduced remarkably by cooking. However, NPU of the cooked whole-seed and dhal samples was significantly higher than in the raw samples. No noticeable differences due to cooking were observed in amino acid composition of whole-seed and dhal samples of these cultivars.
\end{abstract}

\section{Introduction}

Pigeonpea (Cajanus cajan (L.) Millsp.) grain constitutes an important component of the human diet in developing countries, particularly those located in tropical and subtropical areas. India accounts for over $80 \%$ of the world's supply of pigeonpea [9]. Other countries where pigeonpea is an important food legume are Myanmar, Nepal, Kenya, Malawi, Tanzania, and countries of the Caribbean region [16].

Grain legumes supplement cereal-based food by improving its protein quality, when the cereals and legumes are consumed in an appropriate ratio [2]. Like other grain legumes, pigeonpea is a good protein source and hence important for human nutrition [16]. Some of the important factors that affect the protein quality of pigeonpea are protein digestibility and aminoacid composition [17]. People consume pigeonpea in various ways. Wholeseed and dhal (decorticated split cotyledons) of pigeonpea are cooked to a 
desirable softness and consumed along with cereals. Developing green-seeds of pigeonpea are used as a vegetable in parts of India, and some African, Latin American, and Caribbean countries [8].

The cooking process not only improves the palatability of pigeonpea but it destroys or minimizes some antinutritional factors [15]. It has been long recognized that nutritive value and protein digestibility of legumes are very poor unless subjected to cooking or some other form of heat treatment [11]. The occurrence of polyphenols in food legumes has been previously reported by several workers $[3-5,11-12,14]$. It has been shown that polyphenols in beans decrease protein digestibility in animals and in man, probably by making protein partially unavailable or by inhibiting digestive enzymes [3]. Polyphenols of pigeonpea showed considerable variation with plant varieties and cooking processes [12]. Previous studies have found a negative correlation between tannin contents and digestibility of legume proteins [4]. The polyphenolic compounds have been reported to reduce the protein digestibility in beans [3]. The objective of the present investigation is to study the effects of seed polyphenols and cooking process on protein digestibility, biological value, net protein utilization and amino acid composition of pigeonpea.

\section{Materials and methods}

Pigeonpea cultivars, C 11 (brown) and Nylon (White), were grown under similar conditions in the 1986 rainy season at ICRISAT Center, Patancheru $\left(17^{\circ} \mathrm{N}\right)$ near Hyderabad, India. In addition, four pigeonpea cultivars (ICPL 87, ICPL 151, ICPL 87067, and BDN 2) differing in seed-coat color were studied. These cultivars were also grown under similar conditions in the 1988 rainy season at ICRISAT Center, Patancheru $\left(17^{\circ} \mathrm{N}\right)$, near Hyderabad, India. Seed samples of the replicated trials of these cultivars were bulked to get sufficient quantity of seed material for the present investigation. After harvest, grains were cleaned and stored in a cold room $\left(5^{\circ} \mathrm{C}\right)$ until analyzed.

Dehulling and grinding. For preparation of dhal samples (decorticated split cotyledons), a tangential abrasive dehulling device (TADD) was used. Seeds were moistened and then dried in the oven at $55^{\circ} \mathrm{C}$ overnight. The seed-coat was removed in a TADD mill and the dehulled fraction is henceforth referred to as dhal. Whole-seed and dhal samples were ground to a fine powder in a Udy cyclone mill. Samples were defatted in Soxhlet apparatus using $\mathrm{n}$-hexane. 
Determination of seed-coat. The seed-coat fraction was determined by manually separating the seed-coat from the cotyledons. The seed samples were soaked in distilled water for $16 \mathrm{~h}$ at room temperature $\left(25 \pm 1^{\circ} \mathrm{C}\right)$ and the seed-coat removed manually using forceps. Both cotyledon and seed-coat fractions were dried in the oven at $55^{\circ} \mathrm{C}$ in the oven and weighed. Seed-coat content was expressed as a percentage of the whole-seed sample.

Cooking process. Whole-seed and dhal samples were cooked in a pressure cooker for $15 \mathrm{~min}$ at $15 \mathrm{lb}$ pressure. After cooking, the whole broth was freeze-dried and used for analysis and rat feeding trails.

Polyphenols and crude fiber. The polyphenols were extracted from the defatted sample $(500 \mathrm{mg})$ by refluxing with $50 \mathrm{ml}$ of methanol containing $1 \% \mathrm{HCl}$ for $2 \mathrm{~h}$. The extract was concentrated in a rotary flash evaporator and the final volume increased to $50 \mathrm{ml}$ with acidified methanol. The amounts of total polyphenolic compounds in the extracts were estimated as tannic accid equivalent, according to the Folin-Denis method [20]. Crude fiber in dhal and whole-seed samples was determined according to AOAC procedure [1].

Biological evaluation of protein quality. True protein digestibility (TD), biological value (BV), net protein utilization (NPU), and utilizable protein (UP) were determined by conducting rat-feeding experiments using metabolic cages obtained from Lab Products Inc, New Jersey, USA. Group of five Wistar male rats, weighting about $65 \mathrm{~g}$ were used in these experiments. Each rat was fed a $10 \mathrm{~g}$ diet (dry weight basis), containing $150 \mathrm{mg}$ nitrogen, i.e., isoprotein levels. At the end of a 5-day feeding period, unconsumed diet weight was recorded and total nitrogen intake calculated. The remaining procedures for rat-feeding trials were followed and calculation of TD, BV, NPU, and UP values was made according to Eggum [6].

Amino acid analysis. Defatted samples $(50 \mathrm{mg})$ were refluxed in $50 \mathrm{ml}$ of $6 \mathrm{M}$ $\mathrm{HCl}$ for $24 \mathrm{~h}$. The acid was then removed in a rotary flash evaporator and the residue dissolved in a known volume of citrate buffer ( $\mathrm{pH} 2.2$ ). An aliquot of each sample was analyzed in a Beckman 119-CL amino acid analyzer. As a result of refluxng in $6 \mathrm{M} \mathrm{HCl}$, tryptophan was destroyed and, hence, not determined.

Statistical analysis. For all chemical analyses, except amino acids, two replicates were used to determine each constituent. For biological evaluation, five replicates of randomly chosen rats were used. Replications were $\mathrm{C} 11$ and Nylon was remarkably reduced due to cooking. This might have 
Table 1. Polyphenols and crude fiber contents of low (Nylon) and high (C 11) polyphenol cultivars of pigeonpea

\begin{tabular}{|c|c|c|c|c|c|c|c|c|}
\hline \multirow[t]{3}{*}{ Cultivar } & \multirow{3}{*}{$\begin{array}{l}\text { Seed-coat } \\
\text { color }\end{array}$} & \multirow{3}{*}{$\begin{array}{l}\text { Seed } \\
\text { coat }(\%)\end{array}$} & \multicolumn{2}{|c|}{ Crude fiber $(\%)$} & \multicolumn{4}{|c|}{ Polyphenols (mg/g samples) } \\
\hline & & & \multirow[t]{2}{*}{$a$} & \multirow[t]{2}{*}{$\mathrm{b}$} & \multicolumn{2}{|l|}{ Raw } & \multicolumn{2}{|l|}{ Cooked } \\
\hline & & & & & a & $b$ & a & $b$ \\
\hline C 11 & Brown & 13.2 & 5.3 & 1.0 & 13.5 & 1.4 & 14.0 & 1.2 \\
\hline Nylon & Grey/White & 12.7 & 5.4 & 1.1 & 4.8 & 1.1 & 4.5 & 1.0 \\
\hline $\mathrm{SE}$ & & \pm 0.30 & \pm 0.42 & \pm 0.01 & \pm 0.26 & \pm 0.05 & \pm 0.29 & \pm 0.04 \\
\hline
\end{tabular}

$\mathrm{a}=$ whole-seed, $\mathrm{b}=$ dhal; both based on two determinations for each constituent.

subsamples from one seed lot. Standard error was determined by one-way analysis of variance according to Snedecor and Cochran [19].

\section{Results and discussion}

The polyphenols in whole-seed of C 11 were nearly three times higher than in Nylon whereas such differences disappeared in the dhal samples (Table 1). Differences in the levels of polyphenols were remarkable between the darkand light-seed-coat cultivars, although there may be some possible effects of environmental factors on a polyphenol concentration of these cultivars. The effects of environmental factors on polyphenol content of grain legumes, particularly in pigeonpea, have not been established. The seed-coat of Nylon contributed nearly $80 \%$ and C $1190 \%$ of the total seed polyphenols (Table 1). This supports the findings of previous studies which reported that polyphenols were present in the seed-coat and were associated with seedcoat color in beans [4], pulses [11], and pigeonpea [12]. The cooking process did not reduce the levels of polyphenols when cooking broth was not discarded (Table 1). However, a significant reduction in the polyphenol contents of pigeonpea has been reported when the cooking broth was discarded [12]. The reductions in polyphenols due to soaking and boiling of grain legumes are generally attributed to water-soluble nature of polyphenols $[5,12]$. There were no large differences between these cultivars in crude fiber contents (Table 1). However, crude fibers were concentrated in seed-coat and appeared to have no relationship with seed-coat color, as has been recorded in chickpea [13].

Protein digestibility is of increasing interest in grain legumes in general and pigeonpea in particular [17]. In both raw and cooked whole-seed samples, the TD and BV of Nylon (low polyphenol) was significantly higher than that of $\mathrm{C} 11$ (high polyphenol) as given in Table 2. Interestingly, these differences almost disappeared in dhal samples of these cultivars. The low 


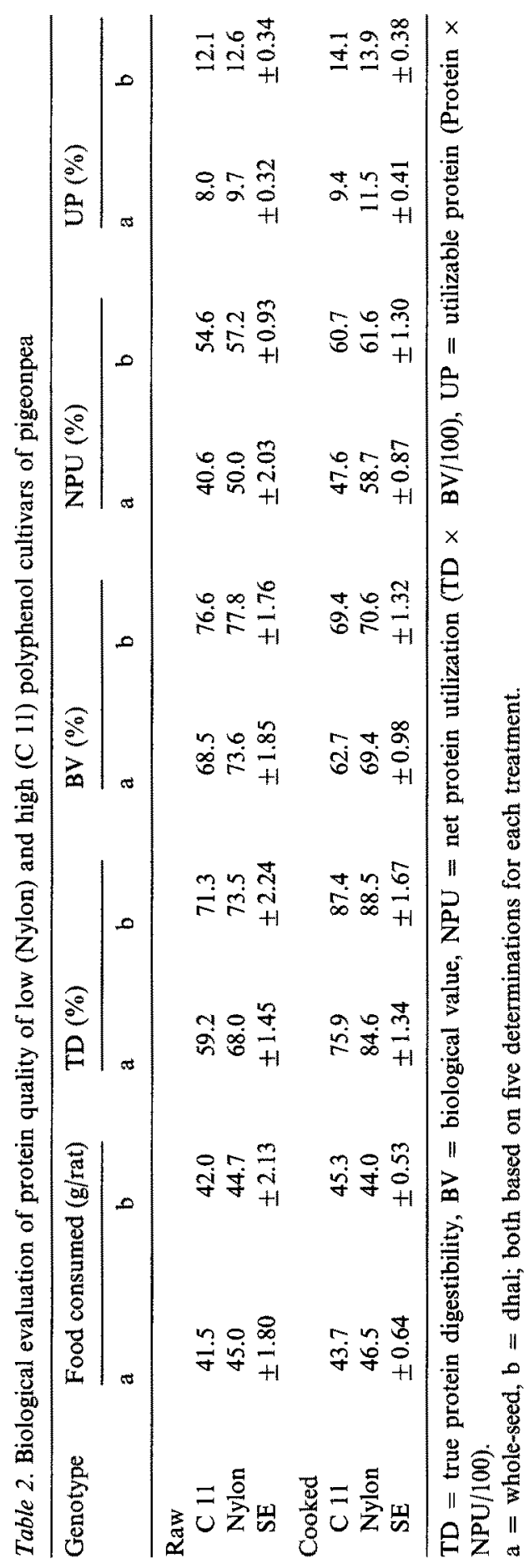


protein digestibility in high polyphenol cultivar and vice-versa suggest a strong association between polyphenols and protein digestibility of pigeonpea. These observations were further confirmed by evaluating four pigeonpea cultivars differing in polyphenol contents and seed color (Table 3). Polyphenol contents of these cultivars ranged between 4.7 and $14.7 \mathrm{mg} / \mathrm{g}$ whereas NPU of these cultivars ranged between 43.1 and $53.6 \%$ (Table 3). It was also noticed that NPU of these cultivars decreased with an increase in polyphenols. This trend was also observed in TD, BV, and UP values of these cultivars (Table 3 ). The reduction in protein digestibility could also be attributed to protein composition. The in vitro protein digestibility was adversely affected by the seed polyphenols of chickpea [18]. No apparent effect of amino acids on protein quality is envisaged as amino acid composition of whole-seed and dhal of $\mathrm{C} 11$ and Nylon did not differ considerably (Table 4). Also, there were no noticeable differences in amino acid contents of Nylon and C 11. Bean protein quality was lower for red and black seed-coat cultivars than for white seed-coat cultivars $[4,5]$. The results of the present study generally support this observation in pigeonpea and suggest that protein quality of pigeonpea cultivars having red and brown seed-coat color would be considerably lower in comparison with that of cultivars with light grey seed-coats because of differences in their contents of polyphenolic compounds.

Seed fibers play an important role in determining the nutritional potential of dietary proteins [10]. In the present study, a comparison of diets containing isoprotein levels and comprising of whole-seed and dhal revealed large differences in NPU and UP in both cooked and raw samples of C 11 and Nylon cultivans. The average NPU was $47.6 \%$ in cooked whole-seed of C 11 and it increased to $60.7 \%$ in dhal (Table 2). The effect of seed-coat (fiber) removal was much less pronounced in Nylon as compared to C 11. This trend in NPU was attributed to differences in polyphenolic compounds of these cultivars as discussed above. However, improvement in NPU and UP of dhal due to the removal of seed-coat in a low polyphenol cultivar (Nylon) indicated a possible interference of fiber in protein utilization in pigeonpea. No large differences in crude fiber content of whole-seed of different cultivars were observed (Tables 1 and 3). But there were differences in TD, BV, NPU, and UP which could be attributed to the differences in polyphenol contents (Table 3 ).

Cooking significantly increased TD in both $\mathrm{C} 11$ and Nylon, and the effect was similar in both whole-seed and dhal samples (Table 2). The increase in TD due to cooking might be attributed to a reduction in the activity of protease inhibitors which interfere in protein digestibility of grain legumes [15]. It was also observed that BV of both whole-seed and dhal samples of 


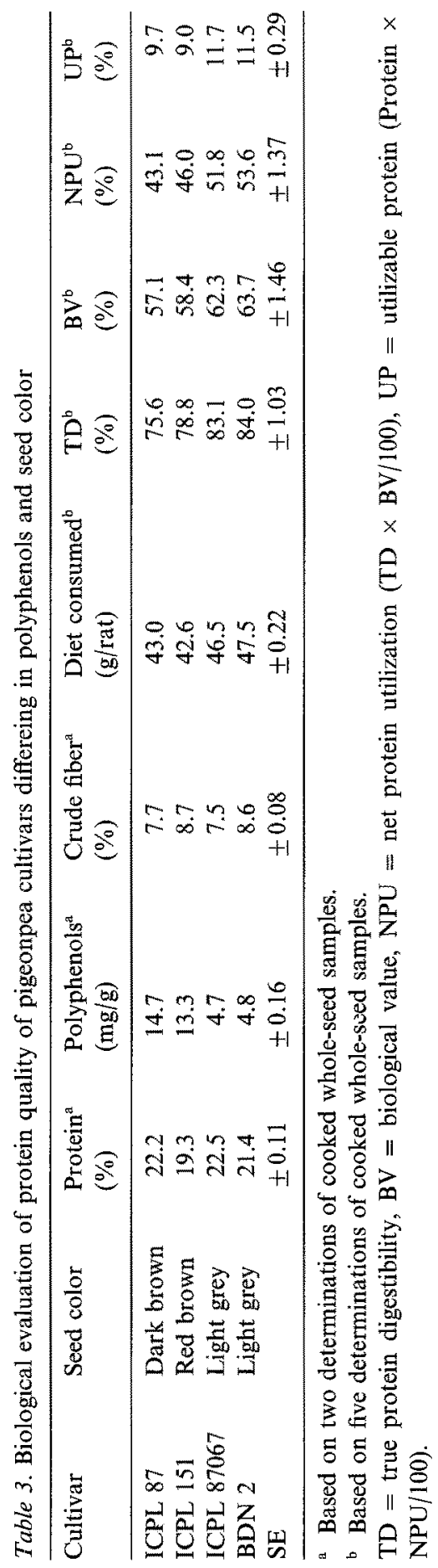


Table 4. Amino acid composition ( $\mathrm{g} / 100 \mathrm{~g}$ protein) of low (Nylon) and high (C 11) polyphenol cultivars of pigeonpea

\begin{tabular}{|c|c|c|c|c|c|c|c|c|}
\hline \multirow[t]{3}{*}{ Amino acid } & \multicolumn{4}{|l|}{ C 11} & \multicolumn{4}{|c|}{ Nylon } \\
\hline & \multicolumn{2}{|l|}{ Raw } & \multicolumn{2}{|c|}{ Cooked } & \multicolumn{2}{|l|}{ Raw } & \multicolumn{2}{|c|}{ Cooked } \\
\hline & a & b & a & b & a & b & a & $\mathrm{b}$ \\
\hline Lysine & 6.7 & 6.7 & 6.2 & 6.2 & 6.8 & 6.9 & 6.3 & 6.4 \\
\hline Histidine & 4.1 & 4.1 & 3.8 & 3.8 & 4.2 & 4.0 & 4.0 & 3.9 \\
\hline Arginine & 6.5 & 6.6 & 6.3 & 6.4 & 6.4 & 7.0 & 6.7 & 6.8 \\
\hline Aspartic acid & 9.2 & 9.2 & 9.3 & 9.3 & 9.6 & 9.6 & 9.6 & 9.4 \\
\hline Threonine & 3.5 & 3.5 & 3.7 & 3.5 & 3.7 & 3.8 & 3.7 & 3.4 \\
\hline Serine & 4.5 & 4.5 & 4.3 & 4.1 & 4.6 & 4.3 & 4.7 & 4.4 \\
\hline Glutamic acid & 17.6 & 18.0 & 17.2 & 17.4 & 17.9 & 17.8 & 18.4 & 18.4 \\
\hline Proline & 4.4 & 4.5 & 4.5 & 4.6 & 4.5 & 4.6 & 4.7 & 4.7 \\
\hline Glycine & 3.6 & 3.7 & 3.5 & 3.8 & 3.7 & 3.7 & 3.9 & 3.6 \\
\hline Alanine & 4.2 & 4.3 & 4.3 & 4.8 & 4.3 & 4.5 & 4.4 & 4.4 \\
\hline Cystine & 0.8 & 0.9 & 0.7 & 1.5 & 1.5 & 1.4 & 1.4 & 1.5 \\
\hline Valine & 4.3 & 4.4 & 4.4 & 4.4 & 4.6 & 4.7 & 4.8 & 4.6 \\
\hline Methionine & 1.5 & 1.5 & 1.6 & 1.5 & 1.5 & 1.4 & 1.4 & 1.5 \\
\hline Isoleucine & 3.8 & 3.8 & 3.9 & 3.9 & 4.0 & 4.2 & 4.3 & 4.0 \\
\hline Leucine & 6.9 & 7.0 & 6.9 & 6.9 & 7.1 & 7.2 & 7.4 & 7.3 \\
\hline Trysine & 3.1 & 3.1 & 3.3 & 3.1 & 3.2 & 3.6 & 3.5 & 3.7 \\
\hline Phenyalanine & 8.5 & 8.7 & 8.5 & 8.6 & 9.0 & 9.4 & 9.6 & 9.7 \\
\hline Total & 93.0 & 94.3 & 91.8 & 93.0 & 96.0 & 99.7 & 98.7 & 97.0 \\
\hline Protein $(\%)^{*}$ & 21.1 & 22.3 & 21.5 & 23.1 & 21.1 & 22.3 & 20.6 & 21.8 \\
\hline
\end{tabular}

$\mathrm{a}=$ whole-seed; $\mathrm{b}=$ dhal.

* Defatted $\mathrm{N} \times 6.25$.

been due to an adverse effect of cooking on the bioavailability of sulfur containing amino acids of pigeonpea, as biological value is directly related to the levels of sulfur-containing amino acids in grain legumes [7]. However, no large effects of cooking on amino acid composition of pigeonpea were noticed (Table 5). The observed reduction in biological value due to cooking in dhal and whole-seed of both low polyphenol and high polyphenol cultivars might rule out the possible involvement of polyphenolic compound in bioavailability of sulfur containing amino acids in pigeonpea. Further, it was also evident that increase in NPU and UP values as a result of cooking was achieved by significant improvement in TD.

\section{Acknowledgement}

Author thanks Dr R. Jambunathan for his encouragement and interest in this study. Technical assistance from P.V. Rao, R. Seetha, and G. Venkates- 
warlu in some of the chemical analyses reported in this paper is gratefully acknowledged.

\section{References}

1. AOAC (1975) Official methods of analysis, 12th ed. Washington DC: Association of Official Analytical Chemists

2. Bressani R (1973) Legumes in human diets and how they might be improved. In: Milner $M$ (ed) Nutritional Improvement of Food Legumes by Breeding. New York: Wiley, pp. $15-42$

3. Bressani R, Eloisa H, Edgar J (1988) Relationship between content and intake of bean polyphenolics and protein digestibility in humans. Plant Foods Hum Nutr 38: 5-21

4. Bressani R, Elias LG, Braham JE (1982) Reduction of digestibility of legume proteins by tannins. J Plant Food 4: 43-45

5. Elias LG, Fernandez DG, Bressani R (1979) Possible effects of seed-coat polyphenolics on the nutritional quality of bean protein. J Food Sci 44: 524-527

6. Eggum BO (1973) A study of certain factors influencing protein utilization in rats and pigs. Copenhagen: National Institute of Animal Science, Report 406

7. Eggum BO, Beames RM (1983) The nutritive value of seed proteins. In: Gottschalk W, Muller HP (eds) Seed Proteins - Biochemistry, Genetics, and Nutritive Value. The Hague: Dr W Junk, $499 \mathrm{p}$

8. Faris DG, Saxena KB, Mazumudar S, Singh U (1987) Vegetable pigeonpea: a promising crop for India. Patancheru, A.P. 502 324, India: International Crops Research Institute for the Semi-Arid Tropics

9. ICRISAT (1986) Annual Report 1985. Patancheru, A.P. 502 324, India: International Crops Research Institute for the Semi-Arid Tropics, $175 \mathrm{p}$

10. Kies C, Fox HM (1978) Fiber and protein nutritional status. Cereal Foods World 23: $249-253$

11. Liener IE (1976) Legume toxins in relation to protein digestibility - A review. J Food Sci 41: $1076-1080$

12. Rao PV, Deosthale YG (1982) Tannin contents of pulse: varietal differences and effects of cooking and germination. J Sci Food Agric 33: 1013-1016

13. Singh U (1984) Dietary fiber and its constituents in desi and kabuli cultivars of chickpea (Cicer arietinum L.). Nutr Rep Int 29: 419-425

14. Singh U (1984) The inhibition of digestive enzymes by polyphenol of chickpea (Cicer arientinum L.) and pigeonpea (Cajanus cajan L.) Nutr Rep Int 2: 745-753

15. Singh U (1988) Antinutritional factors of chickpea and pigeonpea and their removal by processing. Plant Foods Hum Nutr 38: 251-261

16. Singh U (1992) Role of pigeonpea in human nutrition. In: Consultants Meeting on Uses of Grain Legumes (ICRISAT), 27-30 March 1990. Andhra Pradesh, India: International Crops Research Institute for the Semi-Arid Tropics (in press) 